\title{
Mortality of Common pandora (Pagellus erythrinus Linnaeus, 1758) escaping from demersal trawl codends: Water temperature effect
}

\section{Dip trolünün torba kısmından kaçan kırma mercan balığının (Pagellus erythrinus Linnaeus, 1758) ölüm oranları: Su sıcaklığının etkisi}

\author{
F. Ozan Düzbastılar* (D) Altan Lök (D) - Ali Ulaş \\ Ege University, Faculty of Fisheries, 35100 Bornova İzmir, Turkey \\ * Corresponding author: duzbastilar@gmail.com
}

How to cite this paper:

Düzbastllar, O., Lök, A \& Ulaş, A. (2018). Mortality of Common pandora (Pagellus erythrinus Linnaeus, 1758) escaping from demersal trawl codends: Water temperature effect. Ege Journal Fisheries and Aquatic Sciences, 35(2), 181-188. DOI:10.12714/egejfas.2018.35.2.11

\begin{abstract}
In total, 24 replicate hauls were conducted on January-February in 2011 and September in 2012. A tailored bottom trawl with 800 meshes around the mouth was used with covers to retain individuals of common pandora (Pagellus erythrinus). Mortality of fish escaping through $40 \mathrm{~mm}$ square, 44 and $50 \mathrm{~mm}$ diamond mesh codends was investigated by collecting and monitoring the escapees from the codend covers for 7 days. We also observed possible water temperature effect in the escape mortality of common pandora. The escape mortality of common pandora was negligible $(<5 \%)$. No significant difference was demonstrated in the average mortality for all test codends and controls between the winter and the summer $(p>0.05)$. Mesh size and shape was not a significant factor $(p>0.01)$ for the both seasons.
\end{abstract}

Keywords: Escape mortality, bottom trawl, common pandora, water temperature, Aegean Sea

Öz: Ocak-Şubat 2011 ve Eylül 2012 tarihleri arasında toplam 24 trol çekimi yapılmıştır. 800 gözlü kesimli dip trol ağından kaçan kırma mercan (Pagellus erythrinus) bireylerini yakalamak için örtü kullanılmıştır. $40 \mathrm{~mm}$ kare, 44 ve $50 \mathrm{~mm}$ rombik gözlü trol torbalarından kaçan bireylerin ölüm oranları 7 gün boyunca yapılan gözlemler ile tespit edilmiştir. Ayrıca su sıcaklığının kırma mercan ölümleri üzerine etkisi de incelenmiştir. Kırma mercan'ın ölüm oranları düşük bulunmuştur (<\%5). Kış ve yaz mevsimleri için deneme ve kontrol gruplarında saptanan ortalama ölüm oranlarında istatistiksel olarak önemli bir fark bulunmamıştır ( $p>0,05)$. Her iki mevsim için de ağ göz boyutu ve şekli istatistiksel olarak önemli bir faktör değildir $(p>0,01)$.

Anahtar kelimeler: Kaçış mortalitesi, dip trolü, kırma mercan, su sıcakı̆̆ı̆, Ege Denizi

\section{INTRODUCTION}

Escape mortality, which is a component of unaccounted mortality, has been described as pre-catch losses occur fish that escaped and died later (Gilman et al., 2016). The results of escape mortality have been reported approximately for 40 fish species, particularly gadoids and flatfishes, by several researchers (Sangster et al., 1996; Suuronen et al., 1996; Suuronen, 2005; Ingólfsson et al., 2007; Düzbastılar et al., 2010a; Düzbastılar et al., 2010b, c; Düzbastılar, 2014). Information of fishing gear selectivity is essential to good the probability of survival. However, improving the gear selectivity without reducing the injuries of fish escaping from the fishing gear is not applicable to fisheries management (Suuronen, 2005; Guijarro and Massuti, 2006).

Traditional Turkish demersal trawl selectivity is rather poor and has a considerable amount of by-catch and discards (Özbilgin and Tosunoğlu, 2003; Soykan et al., 2016).
Therefore, there are many studies associated with bottom trawls incorporating the selectivity of trawl codends in Turkish fisheries (Özbilgin et al., 2007; Deval et al., 2006; Tosunoğlu et al., 2009). However, studies focusing on the escape mortality of fish escaping from the trawl codend in the Mediterranean Sea are scarce (Metin et al., 2004; Düzbastılar et al., 2010a, b, c; Düzbastilar et al., 2016). Unfortunately, a considerable amount of survival studies does not reflect the commercial trawl fishery (Suuronen, 2005). Because, there are major problems affecting inadequate investigations on survival rates such as mixed-species trawl fishery, some methodological defects (high mortality in control groups, sampling time, catch size etc.), and having extremely complicated and problematic structure (Metin et al., 2004; Suuronen, 2005; Düzbastılar et al., 2010a, c). A small number of fish species escaping from trawl codends was investigated (Metin et al., 2004; Düzbastılar et al. 2010a, b, c; 
Düzbastılar, 2014; Düzbastılar et al., 2016, 2017) while more than 50 species were captured by trawlers in Turkish waters (Tosunoğlu et al., 2003).

One of the major factors causing mortality of trawl-caught fish is water temperature influencing physiological activities and fish behaviours (Özbilgin and Wardle, 2002). However, a few investigations about the water temperature effect on the escape mortality were conducted and most of these so far have not reflected the commercial trawl fishery (Suuronen et al., 2005 Düzbastılar et al., 2010a; Düzbastılar, 2014; Düzbastılar et al., 2017). Nevertheless, the effect of seawater temperature, which is a key factor affecting fish condition, swimming performance (Özbilgin and Wardle, 2002), spawning stage (Özbilgin et al., 2007), healing of gear-induced wounds (Suuronen, 2005 Suuronen et al., 2005; Düzbastılar et al., 2015) etc., must be studied in order to understand its function in the escape mortality In this study, the escape mortality of common pandora, which is targeted species by commercial trawls in the Aegean Sea and the effect of water temperature on the mortality of fish escaping from trawl codends was reported. In addition, the condition factor of common pandora was calculated in order to determine the difference between the escapees and the season.

\section{MATERIALS AND METHODS}

Two experiments were conducted by R/V EGESÜF (26.8 Loa, $405 \mathrm{~kW}$ ) in the İzmir Bay (Aegean Sea, Turkish coast) during the periods 26 January-4 February 2011, and 8-16 September 2008. A conventional bottom trawl (800 meshes) was used in samplings (Fig. $1 \mathrm{~A}-\mathrm{C})$. Three polyethylene (PE) codends (40 mm square, 44 and $50 \mathrm{~mm}$ diamond mesh) were tested. A total of 24 hauls with 15 min tow duration ( 6 control + 18 test cages) were performed in depths of $10-30 \mathrm{~m}$ for the both seasons, located between lat $38.38333^{\circ}-38.40000^{\circ} \mathrm{N}$ and long $26.78333^{\circ}-26.80000^{\circ} \mathrm{E}$. Sea water temperature around the cages were measured using a digital thermometer by divers three times a day.

In total, 9 hauls ( 3 experiments $\times 3$ replicates) were conducted for test cages for each year. For the control category, which were defined as open codend, the trawl codend was opened and fish were caught in codend cover. In the test hauls, a same type of cover was used to collect escapees. Covers $(7.5 \mathrm{~m}$ in length and $0.8 \mathrm{~m}$ in radius) were made of knotless polyamide (PA) netting in $24 \mathrm{~mm}$ mesh size. At the end of each haul, the cover was detached from the trawl, moved and fixed to the sea ground ( $<10 \mathrm{~m}$ ) by divers (Fig. 2).

Control and test cages were observed by divers three times a day for 7 days. The mortalities were collected and the survivors were fed by divers using one-meter-long zipper mounted three different locations of the cover. All dead fish were transferred to the laboratory for measurement. At the end of the monitoring period (on day 8), survivors in all the cages were retrieved. The number of dead and survived fish along with information of their size ranges, mean, min and max lengths, and standard deviation (s.d.) of the size distribution are obtained. Total ( $T L)$ and standard lengths (SL) of dead fishes and survivors were measured to the nearest $\mathrm{mm}$. Escape mortality $\left(F_{\mathrm{E}}\right)$ was calculated by the equation, where $n_{\mathrm{m}}$ is the number of mortalities, and $n$ is the total number of escaped fish in a cage.

$$
F_{E}=\frac{n_{m}}{n} \times 100
$$

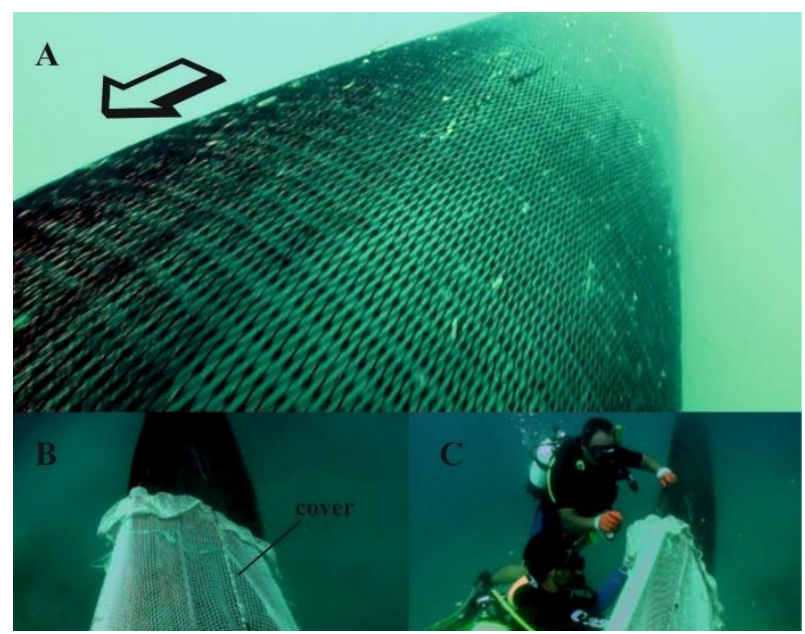

Figure 1. A. Bottom trawl surveys were successfully performed maintaining a continuous towing speed of 2.7 knots. B. Codend cover was attached to the codend using a thin polypropylene (PP) rope $\mathbf{C}$. Codend cover was detached from the codend by cutting the rope very quickly connecting the cover and the codend by divers (Underwater video recordings were performed by Altan Lök)

The underwater observations (the behaviour of the captive fish, trawl performance and underwater works) were recorded by an underwater camera (Sony PC350E with housing Sea\&Sea) by divers in the form of video clips.

Fulton's condition factor $(K)$ was calculated from the weight and total length of the fish using the formula of Fulton (1904) to determine the possible variation between months (January and September) on fish condition:

$$
K=\frac{(\text { weight }[g] \times 100)}{\text { length }^{3}\left[\mathrm{~cm}^{3}\right]}
$$

The length ( $T L)$-weight $(W)$ relationship was estimated by using the equation (Ricker, 1973), where $a$ and $b$ are the coefficients calculated by the least squares method.

$$
\begin{gathered}
W=\log a+b \log T L \\
W=a L^{b}
\end{gathered}
$$

The effect of water temperature on the mortality of test codends $(40 \mathrm{~mm}$ square, 44 and $50 \mathrm{~mm}$ diamond mesh codends) in length groups was tested by t-test. ANOVA was used to determine whether there is a significant difference between mortality rates of test codends. The difference between each of two test codends was analysed by t-test. Ftest was used to analyse the condition factor of survivors in different codends and seasons. 


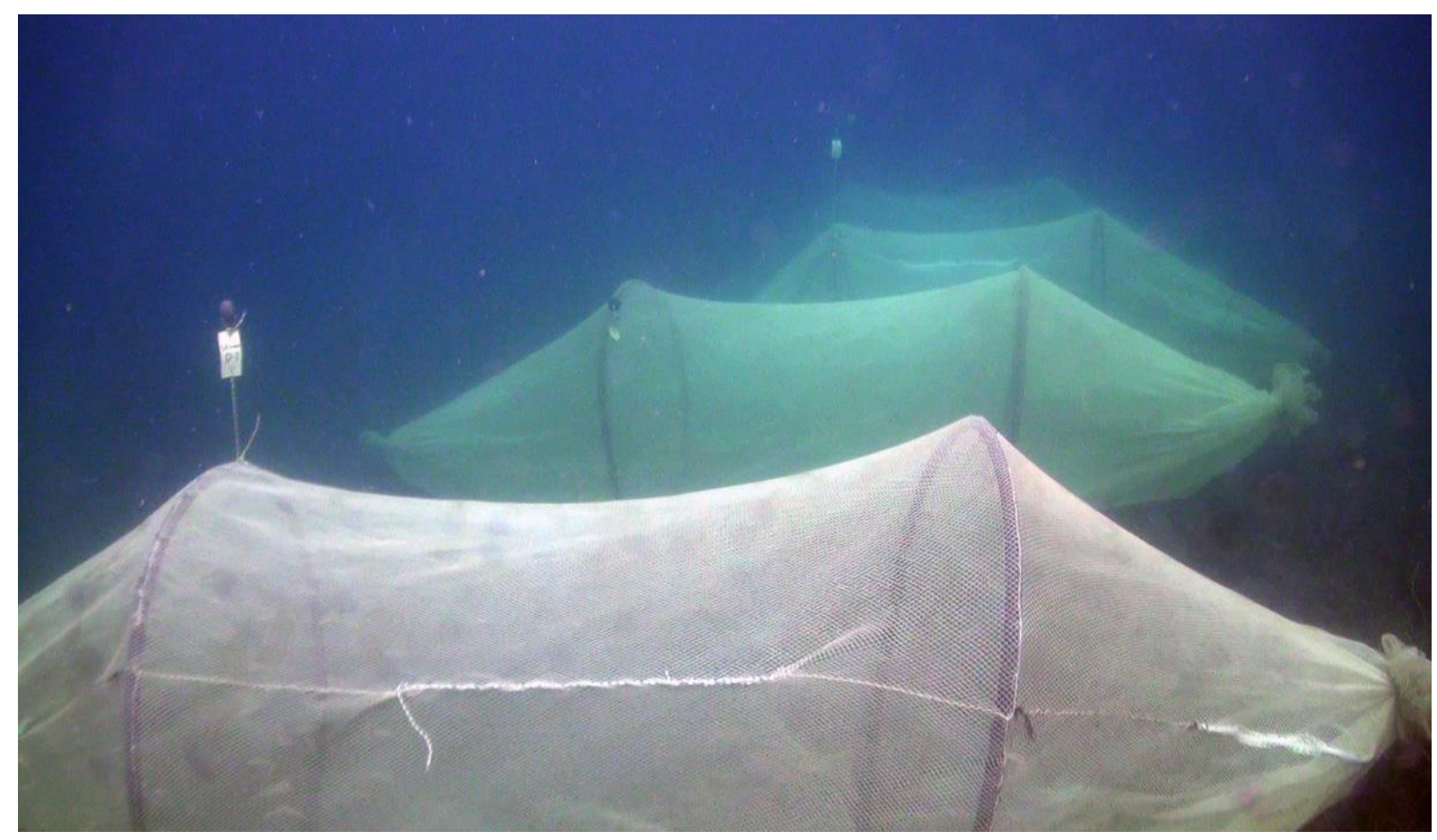

Figure 2: The settlement of codend covers were used as an observation cage during the experiments (Underwater video recordings were performed by F. Ozan Düzbastılar)

\section{RESULTS}

In winter 2011, 12 hauls were conducted. Mean water temperature was $13^{\circ} \mathrm{C}$ at the cage site. In test and control cages, red mullet (Mullus barbatus) was the most abundant species (931), followed by solenette (640) (Buglossidium luteum, Soleidae), scaldfish (514) (Arnoglossus laterna, Bothidae), annular seabream (442) (Diplodus annularis, Sparidae), common pandora (440) (Pagellus erythrinus, Sparidae), blotched picarel (438) (Spicara maena, Centracanthidae), and brown comber (397) (Serranus hepatus, Serranidae). In the catch composition, number of fish and species were differed between years.

In summer 2012, there were 12 hauls and mean temperature was $25^{\circ} \mathrm{C}$ at the study site. In the test and control codends, red mullet was the most captured fish (2743), followed by anchovy (947) (Engraulis encrasicolus, Engraulidae), brown comber (840), red bandfish (668) (Cepola macrophthalma, Cepolidae), blotched picarel (560), black goby (539) (Gobius niger, Gobiidae), solenette (407), and common pandora (292).

The total number of common pandora escaped from $40 \mathrm{~mm}$ square, $44 \mathrm{~mm}$ and $50 \mathrm{~mm}$ diamond mesh codends were 130 , 58 and 81 in winter, respectively (Table 1, Fig. 3). The size of these fish ranged between 5.6 and $13.9 \mathrm{~cm}$. Escape mortality percentages were $1.6,4.3$, and 6.8 in the 3 square mesh codend cages. There was no mortality of common pandora in $44 \mathrm{~mm}$ diamond mesh codends. There were only 3 dead common pandora individuals in cage $1(50 \mathrm{~mm}$ diamond mesh codends), resulted in escape mortality percentage of 5.4. There was no difference in mortality rates between control (mean, $5.3 \% \pm 4.6$ ) and experimental groups (mean, $2 \% \pm 2.7$ ) in winter $(p>0.01)$. Mesh size and shape were not significant factors for the escape morality of common pandora in winter season $(p>0.01)$.

In summer, the total number of common pandora in $40 \mathrm{~mm}$ square, $44 \mathrm{~mm}$ and $50 \mathrm{~mm}$ diamond mesh codends cages were 60,37 , and 71 , respectively (Table 1). The sizes of fish ranged between 5.6 and $14.9 \mathrm{~cm}$ in the six cages population. There were 4 dead individuals in $40 \mathrm{~mm}$ square cages, 3 in $44 \mathrm{~mm}$ diamond cages, and 2 in $50 \mathrm{~mm}$ diamond cages, resulted in mean escape mortality percentages of $2.9,5.9$, and 3.3, respectively (Table 1, Fig. 4). Statistically, there was no difference in the escape mortality rates between control (mean, $4.2 \% \pm 4.6$ ) and test (mean, $4 \% \pm 6.5$ ) cages for summer season $(p>0.01)$. The escape mortality did not differ significantly between test categories $(p>0.01)$. It was concluded that the mortality of common pandora in the test cages for two experiments (2011 and 2012) was negligible and the escape mortality was unrelated to the water temperature effect $(p>0.05)$. 
Table 1. Data of common pandora escaping from square, diamond mesh codends and open codend during winter-2011 and summer-2012 experiments ( $n$ : total fish number; $n_{\mathrm{M}}$ : number of mortalities; $F_{\mathrm{E}}$ : escape mortality in percentage; s.d.: Standard deviation)

\begin{tabular}{|c|c|c|c|c|c|c|c|c|c|c|c|c|c|c|c|}
\hline \multirow{3}{*}{ Cages } & \multirow{3}{*}{$\begin{array}{c}\text { Cage } \\
\text { no }\end{array}$} & \multicolumn{7}{|c|}{ Winter-2011 } & \multicolumn{7}{|c|}{ Summer-2012 } \\
\hline & & \multirow{2}{*}{$n$} & \multirow{2}{*}{$n_{M}$} & \multirow{2}{*}{$F_{\mathrm{E}}$} & \multicolumn{3}{|c|}{ Total length $(\mathrm{cm})$} & \multirow[b]{2}{*}{ s.d. } & \multirow{2}{*}{$n$} & \multirow{2}{*}{$n_{M}$} & \multirow{2}{*}{$F_{\mathrm{E}}$} & \multicolumn{3}{|c|}{ Total length $(\mathrm{cm})$} & \multirow[b]{2}{*}{ s.d. } \\
\hline & & & & & mean & $\min$ & $\max$ & & & & & mean & $\min$ & $\max$ & \\
\hline \multirow[t]{3}{*}{$40 \mathrm{~S}$} & 1 & 63 & 1 & 1.6 & & & & & 46 & 4 & 8.7 & & & & \\
\hline & 2 & 23 & 1 & 4.3 & 9.7 & 5.6 & 13.5 & 1.6 & 9 & 0 & 0.0 & 9.1 & 5.7 & 13.6 & 2.6 \\
\hline & 3 & 44 & 3 & 6.8 & & & & & 5 & 0 & 0.0 & & & & \\
\hline \multirow[t]{3}{*}{$44 D$} & 1 & 28 & 0 & 0.0 & & & & & 15 & 0 & 0.0 & & & & \\
\hline & 2 & 13 & 0 & 0.0 & 10.1 & 6.5 & 13.9 & 1.6 & 17 & 3 & 17.6 & 10.4 & 6.0 & 14.0 & 2.8 \\
\hline & 3 & 17 & 0 & 0.0 & & & & & 5 & 0 & 0.0 & & & & \\
\hline \multirow[t]{3}{*}{$50 \mathrm{D}$} & 1 & 56 & 3 & 5.4 & & & & & 40 & 0 & 0.0 & & & & \\
\hline & 2 & 11 & 0 & 0.0 & 9.8 & 6.5 & 13.3 & 1.4 & 20 & 2 & 10.0 & 11.4 & 5.6 & 14.9 & 2.7 \\
\hline & 3 & 14 & 0 & 0.0 & & & & & 11 & 0 & 0.0 & & & & \\
\hline \multirow[t]{3}{*}{ OC } & 1 & 72 & 0 & 0.0 & & & & & 110 & 4 & 3.6 & & & & \\
\hline & 2 & 86 & 7 & 8.1 & 10.1 & 5.0 & 18.8 & 2.2 & 11 & 1 & 9.1 & 11.7 & 6.2 & 16.3 & 2.5 \\
\hline & 3 & 13 & 1 & 7.7 & & & & & 3 & 0 & 0.0 & & & & \\
\hline
\end{tabular}

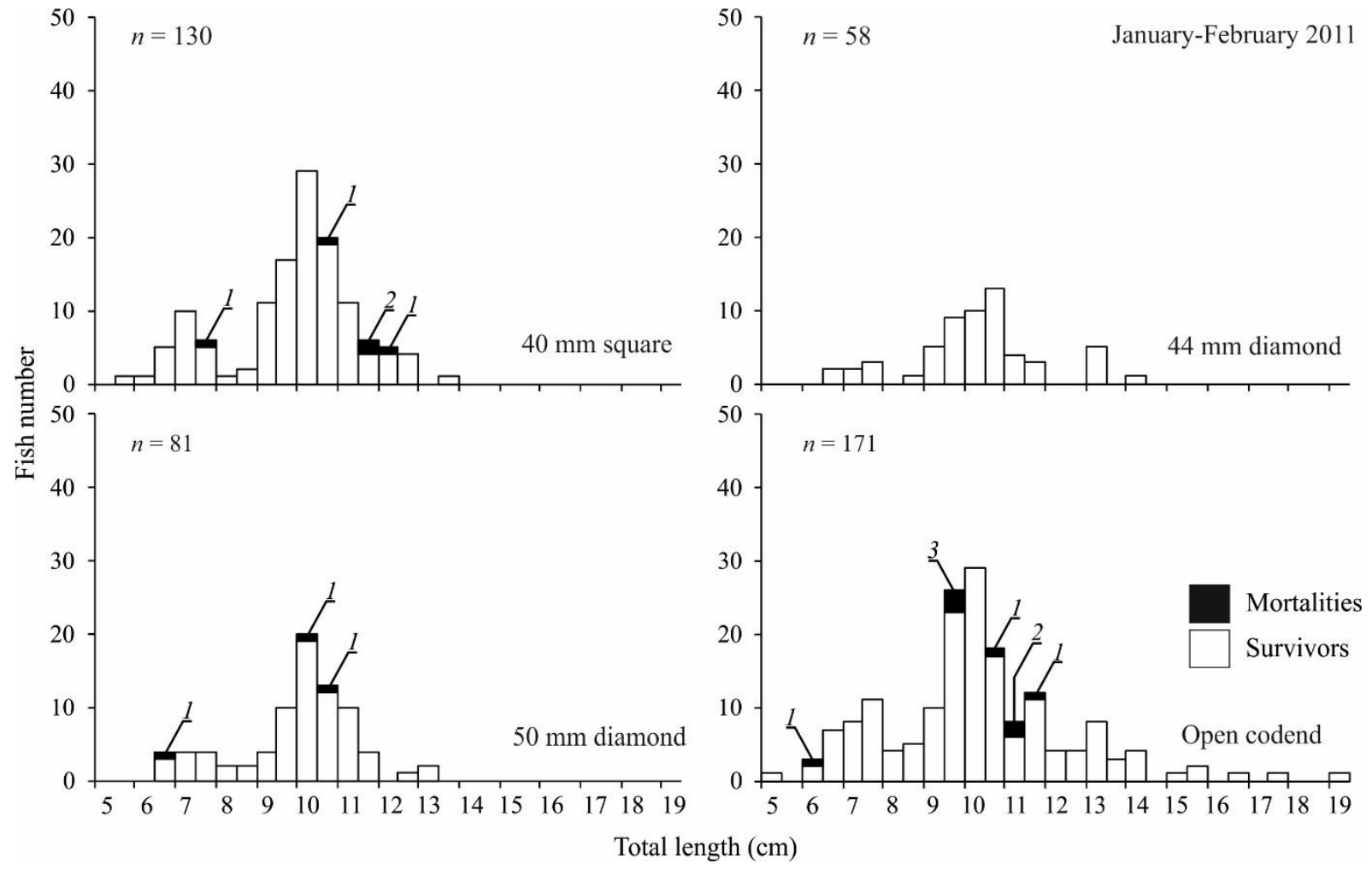

Figure 3: Common pandora in the codends (winter 2011): numbers of mortalities and survivors in each length class for the combined data of the test (40 mm square, 44 and $50 \mathrm{~mm}$ diamond) and open codend cages ( $n$ : number of fish) 


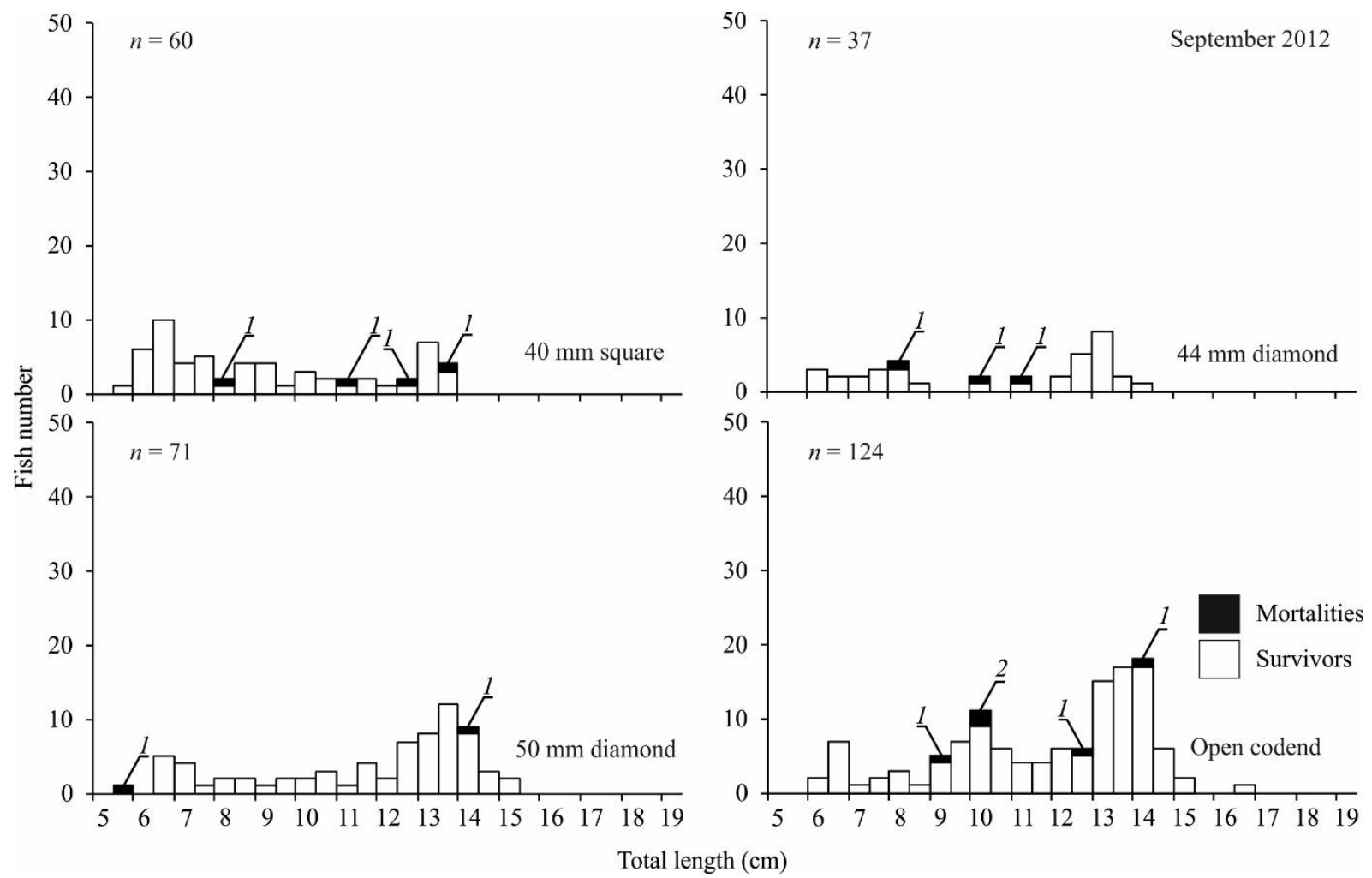

Figure 4: Common pandora in the codends (summer 2012): numbers of mortalities and survivors in each length class for the combined data of the test ( $40 \mathrm{~mm}$ square, 44 and $50 \mathrm{~mm}$ diamond) and open codend cages ( $n$ : number of fish)

The calculated LWR parameters of common pandora in the combined test and open codends were presented in Figure 5. Fulton's condition factor $\left(K_{\mathrm{M}}\right)$ for survivors in $40 \mathrm{~mm}$ square, 44 and $50 \mathrm{~mm}$ diamond mesh codends, and open codends were $1.22( \pm 0.07), 1.17( \pm 0.06), 1.21( \pm 0.08)$, and $1.21( \pm 0.14)$ in winter, 2011, respectively (Table 2). There were no significant differences in the mean condition factor $(p>0.05)$ between the survivors placed in experimental cages and controls.

In summer 2012, $K_{\mathrm{M}}$ values in $40 \mathrm{~mm}$ square, 44 and 50 $\mathrm{mm}$ diamond mesh codends, and open codends were 1.37
$( \pm 0.21), \quad 1.33( \pm 0.18), \quad 1.38( \pm 0.17)$, and $1.49( \pm 0.21)$, respectively (Table 2). No significant difference from test and control cages was found $(p>0.05)$.

However, for the survivors in the open codend cages, there were significant differences for the mean calculated condition factor between winter (1.21) and summer $(1.49)(p<0.05)$. In the 3 test cages $(40 \mathrm{~mm}$ square, $44 \mathrm{~mm}$ and $50 \mathrm{~mm}$ diamond mesh codends), there was significant differences in condition factor between winter and summer seasons $(p<0.05)$.

Table 2. Length-weight relationship of common pandora survivors escaping from square, diamond mesh codends and open codend during winter-2011 and summer-2012 experiments (a: Intercept; $b$ : Slope of the linear regression; CF: Condition factor; $K_{\mathrm{M}}$ : The mean calculated

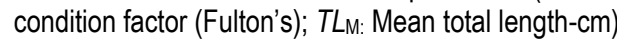

\begin{tabular}{|c|c|c|c|c|c|c|c|c|c|c|}
\hline & \multicolumn{5}{|c|}{ Winter-2011 } & \multicolumn{5}{|c|}{ Summer-2012 } \\
\hline & $a$ & $b$ & $C F$ & $K_{M}$ & $T L_{M}$ & $a$ & $b$ & $C F$ & $K_{M}$ & $T L_{M}$ \\
\hline \multicolumn{11}{|l|}{ Survivors } \\
\hline $40 \mathrm{~mm}$ square & 0.01 & 2.99 & 1.25 & $1.22 \pm 0.07$ & 9.6 & 0.01 & 3.09 & 1.13 & $1.37 \pm 0.21$ & 9.0 \\
\hline $44 \mathrm{~mm}$ diamond & 0.01 & 2.89 & 1.51 & $1.17 \pm 0.06$ & 9.4 & 0.02 & 2.93 & 1.56 & $1.33 \pm 0.18$ & 10.4 \\
\hline $50 \mathrm{~mm}$ diamond & 0.01 & 3.03 & 1.13 & $1.21 \pm 0.08$ & 9.8 & 0.02 & 2.94 & 1.60 & $1.38 \pm 0.17$ & 11.6 \\
\hline Open codend & 0.02 & 2.89 & 1.53 & $1.21 \pm 0.14$ & 9.8 & 0.02 & 2.85 & 2.14 & $1.49 \pm 0.21$ & 11.7 \\
\hline
\end{tabular}




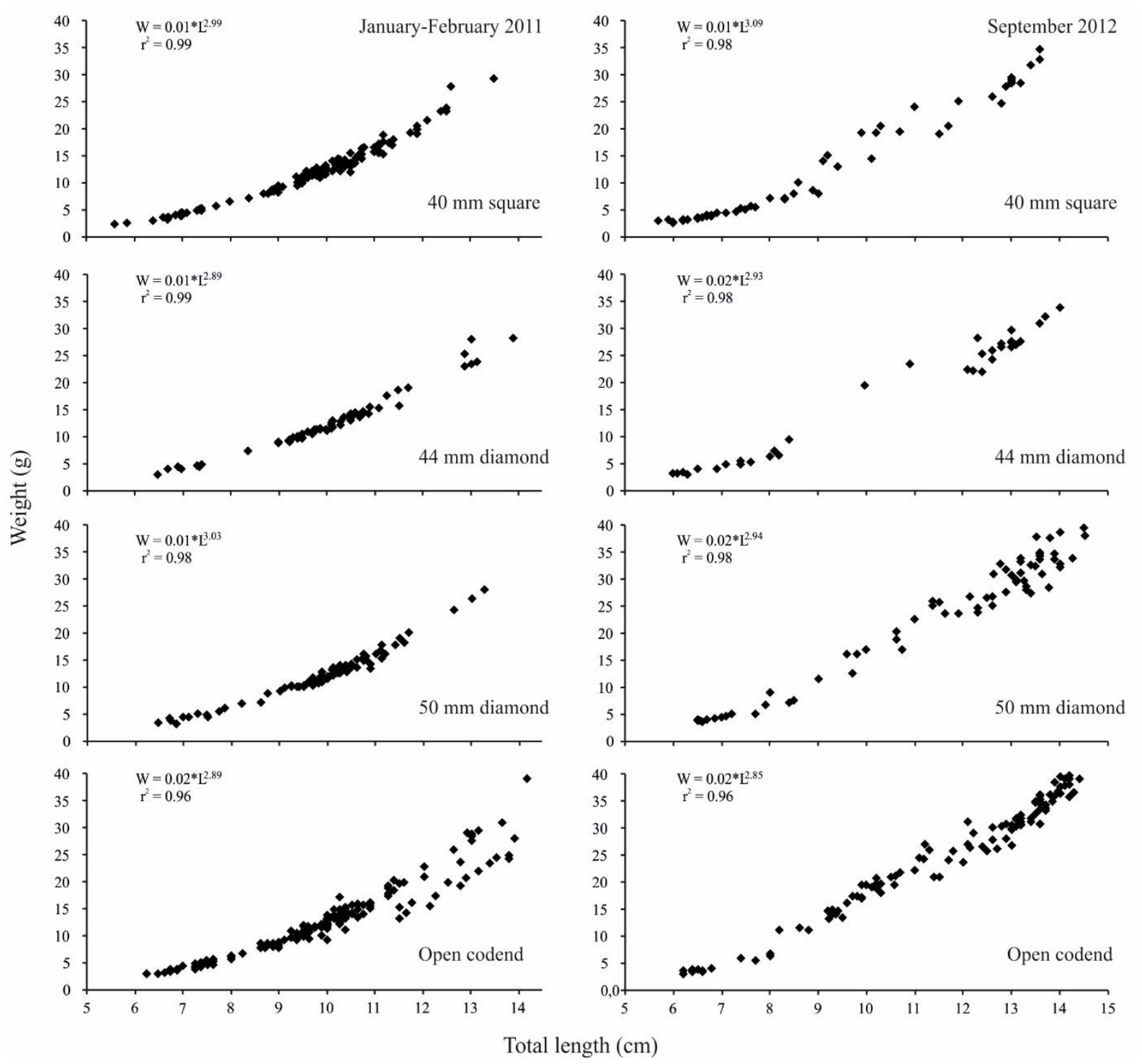

Figure 5: Total length-weight relationship of survivors for the all test and open codend cages in winter and summer

\section{DISCUSSION}

The aims of this study were to investigate the escape mortality rates of common pandora for square and diamond mesh codends and the effect of water temperature on those rates. In addition, the condition factor of survivors was calculated to show the possible difference between the test and control groups and seasons. In the experiments, open codend was used to capture common pandora individuals in similar size range likewise the control groups in order to compare test cages.

The escape mortality depends on many factors such as fish species and size, mesh size and shape, catch size and composition, water temperature, fishing gear properties (Sangster et al., 1996; Suuronen, 2005; Broadhurst et al., 2006; Ingólfsson et al., 2007; Düzbastılar et al., 2017). We focused on the effects of mesh size and shape by considering water temperature and condition factor, which are accounted to be seasonal effects, on the escape mortality for common pandora. Therefore, three different codends were tested to demonstrate the effects of mesh size and shape on the mortality of fish escaping from trawl codends. However, the mortality was not affected by mesh size and shape for both seasons. Similarly, some studies have reported that mesh size was not related to fish mortality or had less influence on the escape mortality (Sangster et al., 1996; Suuronen et al., 1996). The mesh shape has an important role for decreasing the escape mortality, because fish may pass more easily through square mesh codends than diamond mesh codends (Suuronen, 2005). In the experiments, we tested one square and two diamond mesh codends and average morality rates of $40 \mathrm{~mm}$ square, $44 \mathrm{~mm}$ and $50 \mathrm{~mm}$ diamond mesh codends were $4.2 \%, 0 \%$, and $1.8 \%$, 
respectively in winter, 2011. Likewise, we observed low mortality, as $2.9,5.9$, and $3.3 \%$, respectively, for the above mentioned codends respectively in summer 2012. Düzbastılar et al. (2010b) reported that the square mesh $(40 \mathrm{~mm})$ codend cages had a greater mean survival rate of red mullet than that of the diamond mesh $(40 \mathrm{~mm})$ codend cages.

The average mortality rates of common pandora in the test cages did not differ significantly between winter $(2.0 \%$; s.e.: 0.91) and summer (4.0\%; s.e.:2.17). Similarly, control cages were not seriously different in winter and summer, resulting in average mortality rates of $5.3 \%$ and $4.2 \%$, respectively. Low water temperatures may affect the behaviour of fish, which influences fish swimming performance and escapement of fish from the codends (He and Wardle, 1988; Özbilgin and Wardle, 2002). Nevertheless, Suuronen et al. (2005) observed lower mortality $(<3 \%$ ) of Atlantic cod (Gadus morhua) at lower water temperatures $\left(<10^{\circ} \mathrm{C}\right.$ compared to $\left.>15^{\circ} \mathrm{C}\right)$. Higher mortalities (up to $75 \%$ ) were determined when the observation cages were held at higher temperatures because of the cover-cage method as described by Lehtonen et al. (1998). Düzbastılar et al. (2017) found that mean escape mortality of mullet for all trawl hauls in winter $(33.2 \% \pm 6.51)$ was higher than that in summer (26.5\% \pm 6.19$)$. Likewise, Düzbastılar (2014) reported higher mortality rates (between 61.3-95.3\%) for red bandfish at higher seawater temperatures $\left(<13^{\circ} \mathrm{C}\right.$ and compared to $\left.>24.9^{\circ} \mathrm{C}\right)$. However, Düzbastılar et al. (2010a) found that the mortality of brown comber (2.2\% in winter and $1.9 \%$ in summer) escaping from diamond mesh codends was not affected by seawater temperature $\left(<13^{\circ} \mathrm{C}\right.$ and compared to $\left.>24^{\circ} \mathrm{C}\right)$.

Fish condition varies with fish size (Ricker, 1973) and is associated with age, sex, environment, water temperature, feeding pattern, and stress factors (Barton and Schreck, 1987; Brown et al., 1987; Bolger and Connolly, 1989; Carscadden and Frank, 2002). We used Fulton's condition factor $\left(K_{M}\right)$, which is one of the condition indices, to determine the possible difference between the survivors of test and control cages and season. $K_{M}$ was calculated for 346 survivors observed in the test and control cages, which varied in the range between 1.17 and 1.22 in winter 2011. In summer 2012, $K_{M}$ values were calculated for 280 survivors and ranged between 1.33 and 1.49 . We found that the condition index, which is the one of seasonal

\section{REFERENCES}

Barton, B.A. \& Schreck, C.B. (1987). Metabolic cost of acute physical stress in juvenile steelhead. Transactions of the American Fisheries Society, 116 257-263. DOI: 10.1577/1548-8659(1987)116<257: MCOAPS>2.0.CO;2

Bolger, T. \& Connolly, P.L. (1989). The selection of suitable indices for the measurement and analysis of fish condition. Journal of Fish Biology, 34: 171-182. DOI: 10.1111/j.1095-8649.1989.tb03300.x

Broadhurst, M.K., Suuronen, P., \& Hulme A. (2006). Estimating collateral mortality from towed fishing gear. Fish and Fisheries, 7: 180-218. DOI: 10.1111/j.1467-2979.2006.00213.x

Brown, J.A., Johansen, P.H., Colgan, P.W. \& Mathers, R.A. (1987). Impairment of early feeding behaviour of largemouth bass by pentachloropheno exposure: a preliminary assessment. Transactions of the American factors, did not differ between the test cages and control in winter. Differences in $K_{M}$ values for summer season showed similar results. Fulton's condition factor differed significantly from winter (mean, 1.20) to summer (mean, 1.40). Conversely, the results of condition factor did not affect the mortality rate between winter and summer. Likewise, Düzbastılar et al. (2017) determined that in terms of $\mathrm{K}$ factor, there was no significant difference between dead fish and survivors $(p>0.01)$ of the escapees of red mullet for all the hauls in summer and winter seasons. In experiments, average total lengths of fish passed through the codend meshes were $9.9 \mathrm{~cm}$ ( $\mathrm{min}, 5.6 \mathrm{~cm}$ and max, $13.9 \mathrm{~cm}$ ) and $10.3 \mathrm{~cm}$ (min, $5.6 \mathrm{~cm}$ and $\max , 14.9)$, in winter and summer respectively. The weight of fish in test cages was $12.2 \mathrm{~g}$ in winter and $18.1 \mathrm{~g}$ in summer. Metin et al. (2013) reported the total lengths at first maturity of females and males to be 11.30 and $15.08 \mathrm{~cm}$, respectively in Izmir Bay, in the central Aegean Sea. Although the difference at the condition factors between winter and summer periods was a significant, it was not effective on the escape mortality. This result might be stem from the escaped fish are smaller than its first maturity length.

This study determines that codend escape mortality for common pandora is not related to mesh shape and size of trawl codend and the effect of water temperature. We concluded that the mortality of the species escaping from trawl codend was negligible although experimental conditions did not reflect the commercial fishing conditions. On the other hand, to develop our knowledge on the management strategy, the escape mortality investigations should be conducted for various fish species in addition to selectivity studies to decrease mortality by using selective devices, and new materials (soft and knotless fibres).

\section{ACKNOWLEDGEMENTS}

In the study, part of the data from TÜBITAK (Scientific and Technological Research Council of Turkey) project 1100335 and EBILTEM (Ege University Science and Technology Centre) project 2012/BiL/034 was used. We would like to thank the TÜBITAK and EBILTEM for financial support as well as our colleagues for their assistance during the experiments.

Fisheries Society, 116: 71-78.

DOI: 10.1577/1548-8659(1987)116<71:IOEFBO>2.0.CO;2

Carscadden, J.E. \& Frank, K.T. (2002). Temporal variability in the condition factors of Newfoundland capelin (Mallotus villosus) during the past two decades. ICES Journal of Marine Science, 59, 950-958. DOI: 10.1006/jmsc.2002.1234

Deval, M.C., Bök, T., Ateş, C. \& Özbilgin, H. (2006). Selectivity of PE and PA material codends for rose shrimp Parapenaus longirostis in Turkish twin rigged beam trawl fishery. Fisheries Research, 81, 72-79. DOI: 10.1016/j.fishres.2006.05.007

Düzbastılar, F.O., Özgül, A., Aydın, İ., Gül, B. \& Soykan, O. (2010a). A preliminary study on the survival of brown comber, Serranus hepatus 
(Actinopterygii, Perciformes, Serranidae), escaping from the codend of a bottom trawl. Acta Ichthyologica Et Piscatoria, 40, 27-36. DOI: 10.3750/AIP2010.40.1.04

Düzbastılar, F.O., Özbilgin, H., Aydın, C., Metin, G. \& Ulaş, A. (2010b) Mortalities of fish escaping from square and diamond mesh codends in the Aegean Sea. Fisheries Research, 106, 386-392. DOI: 10.1016/j.fishres.2010.09.008

Düzbastılar, F.O., Aydın, C., Metin, G., Lök, A. \& Ulaş, A. (2010c). Survival of fish after escape from a $40 \mathrm{~mm}$ streched diamond mesh trawl codend in the Aegean Sea. Scienta Marina, 74(4), 755-761. DOI: $10.3989 /$ scimar.2010.74n4755

Düzbastılar, F.O. (2014). Determining escape mortality of red bandfish (Cepola macrophthalma) escaping from bottom trawl (in Turkish). Ege Journal of Fisheries and Aquatic Sciences, 31(2), 61-68. DOI: 10.12714/egejfas.2014.31.2.02

Düzbastılar, F.O., Laleli, T., Özgül, A. \& Metin, G. (2015). Determining the severity of skin injuries of red mullet, Mullus barbatus (Actinopterygii: Perciformes: Mullidae), inflicted during escape from trawl codend. Acta Ichthyologica Et Piscatoria, 45(1), 75-83. DOI: 10.3750/AIP2015.45.1.08

Düzbastılar, F.O., Aydın, C. \& Gül, B. (2016). Mortality of non-target flatfishes escaping from demersal trawl codends. Journal of Applied Ichthyology, 32 1194-1204. DOI: 10.1111/jai.13220

Düzbastılar, F.O., Breen, M., Aydın, C., Özbilgin, H., Özgül, A., Ulaş, A., Metin G., Gül, B. \& Lök, A. (2017). Seasonal variation in mortality of red mullet (Mullus barbatus) escaping from codends of three different sizes in the Aegean Sea. Scienta Marina, 81(3): 339-349. DOI: $10.3989 /$ scimar.04600.19A

Fulton, T.W. (1904). The rate of growth of fishes. Fisheries Board of Scotland Annual Report 22. Edinburgh (Part 3).

Gilman, E., Suuronen, P., Hall, M. \& Kennelly, S. (2016). Causes and methods to estimate cryptic sources of fishing mortality. Journal of Fish Biology, 83, 766-803. DOI: $10.1111 / \mathrm{jfb} .12148$

Guijarro, B. \& Massuti, E. (2006). Selectivity of diamond- and square-mesh codends in the deepwater crustacean trawl fishery off the Balearic Islands (western Mediterranean). ICES Journal of Marine Science, 63, 52-67. DOI: 10.1016/j.icesjms.2005.08.011

He, P. \& Wardle, C.S. (1988). Endurance at intermediate swimming speeds of Atlantic mackerel, Scomber scombrus L., herring, Clupea harengus L., and saithe, Pollachius virens L. Journal of Fish Biology, 33, 348-360. DOI: 10.1111/j.1095-8649.1988.tb05468.x

Ingólfsson, O.A., Soldal, A.V., Huse, I. \& Breen, M. (2007). Escape mortality of cod, saithe, and haddock in a Barents Sea Trawl Fishery. ICES Journal of Marine Science, 64, 1836-1844. DOI: 10.1093/icesjms/fsm150

Lehtonen, E., Tschernij, V. \& Suuronen, P. (1998). An improved method for studying survival of fish that escape trawl-codend meshes. Fisheries Research, 38, 303-306. DOI: 10.1016/S0165-7836(98)00163-5
Metin, C., Tokaç, A., Ulaş, A., Düzbastılar, F.O., \& Lök, A. (2004). Survival of red mullet (Mullus barbatus L., 1758) after escape from a trawl codend in the Aegean Sea. Fisheries Research, 70, 49-53. DOI: 10.1016/j.fishres.2004.06.013

Metin, G., İlkyaz, A.T., Soykan, O., \& Kınacıgil, H.T. (2013). Biological characteristics of the common pandora, Pagellus erythrinus (Linnaeus, 1758), in the central Aegean Sea. Turkish Journal of Zoology, 35(3), $307-$ 315. DOI: 10.3906/zoo-0904-4

Özbilgin, H., \& Wardle, C.S. (2002). Effect of seasonal temperature changes on the escape behaviour of haddock, Melanogrammus aeglefinus, from the codend. Fisheries Research, 58 (3): 323-331. DOI: 10.1016/S0165-7836(01)00394-0

Özbilgin, H., \& Tosunoğlu, Z. (2003). Comparison of the selectivities of double and single codends. Fisheries Research, 63: 143-147. DOI: 10.1016/S0165-7836(03)00005-5

Özbilgin, H., Tosunoğlu, Z., Tokaç, A., \& Metin, G. (2007). Seasonal variation in the trawl codend selectivity of blotched picarel (Spicara smaris). ICES Journal of Marine Science, 64, 1569-1572. DOI: 10.4194/trjfas.2011.0203

Ricker, W.E., 1973. Linear regressions in fishery research. Journal of the Fisheries Research Board of Canada, 30(3), 409-434. DOI: 10.1139/f73-072

Sangster, G.I., Lehmann, K., \& Breen, M. (1996). Commercial fishing experiments to assess the survival of haddock and whiting after escape from four sizes of diamond mesh codends. Fisheries Research, 25, 323345. DOI: 10.1016/0165-7836(95)00430-0

Soykan, O., Akgül, Ş.A., \& Kınacıgil, H.T. (2016). Catch composition and some other aspects of bottom trawl fishery in Sığacık Bay, central Aegean Sea, eastern Mediterranean. Journal of Applied Ichthyology, 32(3), 542-547. DOI: 10.1111/jai.13042

Suuronen, P., Erickson, D.L., \& Orrensalo, A. (1996). Mortality of herring escaping from pelagic trawl codends. Fisheries Research, 25: 305-321. DOI: 10.1016/0165-7836(95)00446-7

Suuronen, P. (2005). Mortality of fish escaping trawl gears. FAO Fisheries Technical Paper 478, Rome, Italy.

Suuronen, P., Lehtonen, E., \& Jounela, P. (2005). Escape mortality of trawlcaught Baltic cod (Gadus morhua) - the effect of water temperature, fish size and codend catch. Fisheries Research, 71, 151-163. DOI: 10.1016/j.fishres.2004.08.022

Tosunoğlu, Z., Özbilgin, H., \& Özbilgin, Y.D. (2003). Body shape and trawl codend selectivity for nine commercial fish species. Journal of the Marine Biological Association of the United Kingdom, 83, 1309-1313. DOI: $10.1017 / S 0025315403008737$

Tosunoğlu, Z., Aydın, C., Salman, A., \& Fonseca, P. (2009). Selectivity of diamond, hexagonal and square mesh codends for three commercial cephalopods in the Mediterranean. Fisheries Research, 97, 95-102. DOI: 10.1016/j.fishres.2009.01.006 